\title{
Solvent-free Synthesis, Characterization and Biological Activity of Transition Metal Complexes of Schiff Base Ligand Derived from 2-Amino Benzimidazole with 4, 4'Dibromobenzil
}

\author{
Sadashiv N. Sinkar ${ }^{1(D)}$, Mahesh G. Undegaonkar 2(D), Sharad P. Moharir ${ }^{3}$ (D), Sunil R. Mirgane 4,* $^{\text {(*) }}$ \\ Department of Chemistry; MSS'S Arts Science and Commerce College Ambad, Dist. Jalna, India \\ Department of Chemistry; Arts Science and Commerce College Badanapur, Dist. Jalna, India \\ Department of Chemistry; Siddharth Arts Science and Commerce College Jafrabad, Dist.Jalna, India \\ PG \& Research Department of Chemistry; J.E.S. College Jalna, India \\ Correspondence: mirganesunil@gmail.com (S.RM);
}

Scopus Author ID 6506207573

Received: 31.05.2021; Revised: 5.08.2021; Accepted: 9.08.2021; Published: 12.09.2021

\begin{abstract}
Microwave-assisted synthesis and characterization of Schiff base ligand complexes of transition metals such as $\mathrm{Mn}(\mathrm{II}), \mathrm{Fe}(\mathrm{III}), \mathrm{Co}(\mathrm{II}), \mathrm{Ni}(\mathrm{II}), \mathrm{Cu}(\mathrm{II}), \mathrm{Zn}(\mathrm{II}) \mathrm{Cd}(\mathrm{II})$, and $\mathrm{Ag}(\mathrm{I})$ (using Schiff base) prepared by irradiation of 2-Amino benzimidazole with 4,4'dibromo benzil. The Synthesized transition metal complexes and Schiff base ligand have been representatively characterized by elemental analysis and spectral methods such as UV, IR, ${ }^{1} \mathrm{H}-\mathrm{NMR}, \mathrm{LC}-\mathrm{MS}$, and Thermal analysis. The synthesized ligand and its complexes were also screened for their biological activities, such as antibacterial activity against bacterial species Staphylococcus aureus, Escherichia coli, and Salmonella Typhi. The result indicated that the complexes exhibited octahedral geometry.
\end{abstract}

Keywords: microwave synthesis; Schiff base; thermal study; biological activity.

(C) 2021 by the authors. This article is an open-access article distributed under the terms and conditions of the Creative Commons Attribution (CC BY) license (https://creativecommons.org/licenses/by/4.0/).

\section{Introduction}

The microwave-induced enhancement of organic reactions is currently a focus of attention for chemists due to the decreased reaction time, improved yields, and easier work up than conventional methods [1]. In microwave synthesis, low boiling, toxic and poisonous solvents are often avoided to avoid accidents [2]. The use of the microwave for the synthesis of organic compounds has proved to be an efficient, safe, and environmentally benign technique with a shorter reaction time [3]. Schiff's bases are compounds having an azomethine $(\mathrm{C}=\mathrm{N})$ group. Schiff's base ligands were synthesized by the microwave irradiation of primary amines and active carbonyl groups [4,5]. Microwave irradiated reactions under solvent-free or fewer solvent conditions are attractive results in reduced pollution, low cost, and offer high yields together with safety in processing and handling [6-8]. Benzimidazole derivatives are related to several varieties of pharmacokinetic and pharmacodynamics properties[9]. Specifically, this nucleus is a constituent of vitamin B12. The medicinal activities of the benzimidazole containing moiety have been well familiar Albendazole, Mebendazole[10]. Benzimidazole nucleus is one of the bioactive heterocyclic compounds that exhibit a wide range of biological activities. These biological activities include anti-cancer [11-13], 
bactericidal [14], fungicidal [15-17], analgesic [18,19] and anti-viral properties. [20-22] some have Anti-hypertensive activity [23], while some derivatives have been synthesized and evaluated for inhibition of HIV-1 infectivity [24].

Schiff bases are well known for their biological applications as antibacterial, antifungal, and antiviral agents, plant growth inhibitors insecticidal, antidepressant, anti-inflammatory, anti-tuberculosis, and antimicrobial and anticonvulsant drug activity[25]. We have synthesized Schiff base from 2-amino benzimidazole and 4,4' dibromo benzil under microwave irradiation in the present study. We planned the synthesis of new Schiff bases using microwave irradiation due to ease to workup, improved yield, and completion of the reaction time, less [26].

\section{Materials and Methods}

All the synthetic grade, analytical grade reagents as well as chemicals were purchased from Sigma Aldrich, Loba Chem., Merck chemicals. All newly synthesized compounds' melting point was found using an electrothermal digital apparatus and uncorrected. ${ }^{1} \mathrm{H}-\mathrm{NMR}$, spectral data were recorded on a Bruker (400 MHz, $100 \mathrm{MHz}$ ) spectrometer. Chemical shift (ppm) was referred to as the internal standard Tetramethyl silane (TMS). The synthesized compounds find out the molecular weight using LC-MS. The reaction was monitored by thinlayer chromatography.

\subsection{Synthesis of Schiff base ligand.}

The Schiff base has been synthesized by reacting 2-Aminobenzimidazole $(0.28 \mathrm{gm}$, $0.02 \mathrm{mmol})$ and 4,4 dibromo benzil $(0.37 \mathrm{gm}, 0.01 \mathrm{mmol})$. The reaction was carried out in a microwave oven for 30 minutes. The irradiated product was washed with dry ether and filtered. The final product was recrystallized from ethanol to give pale yellow crystals. The purity of the product was monitored by the use of TLC, using n-hexane and ethyl acetate (7:3). Yield $82 \%$, M.P. $198^{\circ} \mathrm{C}$.
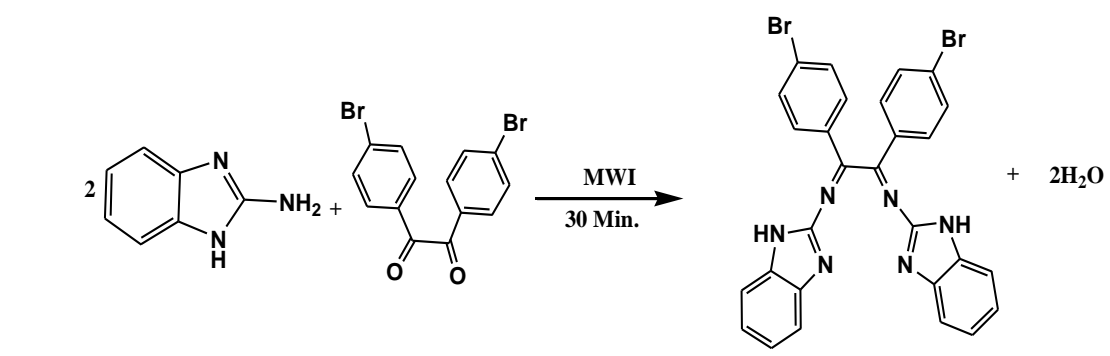

2-Amino Benzimidazole 4,4 dibromo benzil

$\mathrm{N}-((\mathrm{E})-2-(1 \mathrm{H}-\mathrm{benzo}[\mathrm{d}]$ imidazol-2-ylimino)-1,2-bis (4-bromophenyl)ethylidene)-1H-benzo[d]imidazol-2-amine

\subsection{Synthesis of metal complexes.}

The Schiff base ligand and metal salts were mixed in a grinder 1:1 (metal: ligand) ratio. The reaction mixture was then irradiated in a microwave oven. The reaction was completed in a short time, between 30-150 sec. The progress of the reaction and purity of the product was monitored by TLC plate. Each product was recrystallized from ethanol and ether, and finally, different colored crystals were obtained. (Yield: 84-98\%)

\section{Results and Discussion}

In the present study of the microwave-assisted synthesis, it was observed that the reaction time had been drastically reduced with a better yield of the products. The difference 
was observed probably due to the strong microwave effect and the high enhancement of reaction rate. The conformation of results was also checked by repeating the synthesis process[27]. The microwave irradiation technique was completed with 30-150 Sec. and yield 84-98\%. All the metal complexes are colored, solid and stable towards air and moisture at room temperature. They possess a sharp melting point. The complexes are soluble in dimethylformamide and dimethyl sulfoxide but insoluble in common organic solvents3.1. Elemental analysis.

Table 1. Elemental analysis of Schiff base ligand.

\begin{tabular}{c|c|c|c|c|c}
$\begin{array}{c}\text { Molecular formula } \\
\text { (Novel ligand) }\end{array}$ & Mol.Wt. & \multicolumn{5}{|c}{ Found (Calculated) (\%) } \\
\cline { 3 - 6 } & & C & H & N & Br \\
\hline $\mathrm{C}_{28} \mathrm{H}_{18} \mathrm{~N}_{6} \mathrm{Br}_{2}$ & 598 & 54.66 & 3.71 & 15.90 & 25.73 \\
& & $(56.18)$ & $(3.01)$ & $(14.05)$ & $(26.76)$
\end{tabular}

\subsection{Physical properties.}

Table 2. The details of the physical properties of the novel Ligand and its metal complexes.

\begin{tabular}{l|l|l|l|l} 
Sr.No. & Formula of Ligand/Complex & Colour & M.P. $\left({ }^{\circ} \mathrm{C}\right)$ & Yield (\%) \\
\hline 1 & $\mathrm{C}_{28} \mathrm{H}_{18} \mathrm{~N}_{6} \mathrm{Br}_{2}$ & Pale yellow & 198 & 82 \\
\hline 2 & {$\left[\mathrm{MnC}_{28} \mathrm{H}_{18} \mathrm{~N}_{6} \mathrm{Br}_{2}\left(\mathrm{H}_{2} \mathrm{O}\right)_{2}\right]$} & Light Green & 120 & 95 \\
\hline 3 & {$\left[\mathrm{Fe} \mathrm{C}_{28} \mathrm{H}_{18} \mathrm{~N}_{6} \mathrm{Br}_{2}\left(\mathrm{H}_{2} \mathrm{O}\right)_{2}\right]$} & Brown & 188 & 92 \\
\hline 4 & {$\left[\mathrm{Co} \mathrm{C}_{28} \mathrm{H}_{18} \mathrm{~N}_{6} \mathrm{Br}_{2}\left(\mathrm{H}_{2} \mathrm{O}\right)_{2}\right]$} & Brown & 138 & 98 \\
\hline 5 & {$\left[\mathrm{Ni} \mathrm{C}_{28} \mathrm{H}_{18} \mathrm{~N}_{6} \mathrm{Br}_{2}\left(\mathrm{H}_{2} \mathrm{O}\right)_{2}\right]$} & Light Green & $>300$ & 84 \\
\hline 6 & {$\left[\mathrm{Cu} \mathrm{C}_{28} \mathrm{H}_{18} \mathrm{~N}_{6} \mathrm{Br}_{2}\left(\mathrm{H}_{2} \mathrm{O}\right)_{2}\right]$} & Green & $>300$ & 85 \\
\hline 7 & {$\left[\mathrm{Zn} \mathrm{C}_{28} \mathrm{H}_{18} \mathrm{~N}_{6} \mathrm{Br}_{2}\left(\mathrm{H}_{2} \mathrm{O}\right)_{2}\right]$} & Greenish Yellow & 190 & 93 \\
\hline 8 & {$\left[\mathrm{Cd} \mathrm{C}_{28} \mathrm{H}_{18} \mathrm{~N}_{6} \mathrm{Br}_{2}\left(\mathrm{H}_{2} \mathrm{O}\right)_{2}\right]$} & Bright Yellow & 259 & 96 \\
\hline 9 & {$\left[\mathrm{Ag} \mathrm{C}_{28} \mathrm{H}_{18} \mathrm{~N}_{6} \mathrm{Br}_{2}\left(\mathrm{H}_{2} \mathrm{O}\right)_{2}\right]$} & Dark Yellow & 217 & 87
\end{tabular}

\subsection{Infrared spectra.}

The IR spectrum of the ligand is compared with that of the complexes to determine the changes that might have occurred during the complexations. IR spectrum of the Schiff base ligand exhibit the most characteristic band at $v(C=N$, azomethine $), 1668 \mathrm{~cm}^{-1}$ [28-30]. The metal complexes of $\mathrm{Ni}(\mathrm{II})$ and $\mathrm{Cu}$ (II) show broadband at $3304-3321 \mathrm{~cm}^{-1}$ due to the benzimidazole ring's N-H stretching frequency. A medium intensity band at 831 and $819 \mathrm{~cm}^{-1}$ in $\mathrm{Ni}$ (II), $\mathrm{Cu}$ (II), respectively, suggests the presence of coordinated water in these complexes. In the low-frequency region, the band of weak intensity was observed for the complexes in the region $466-467 \mathrm{~cm}^{-1}$ to $(\mathrm{M}-\mathrm{N})$ [31]. The infrared spectral data of the novel ligand and its metal complexes have been presented in Table 3.

Table 3. Selected Infrared frequencies $\left(\mathrm{cm}^{-1}\right)$ of ligand and its complexes.

\begin{tabular}{c|c|c|c|c|c} 
Ligand/Complexes & $\boldsymbol{v}(\mathbf{C}=\mathbf{N}) A z o m e t h i n e$ & $\boldsymbol{v}(\mathbf{N}-\mathbf{H})$ Imidazole & $\boldsymbol{v}(\mathbf{C}-\mathbf{B r})$ & $\boldsymbol{v}(\mathbf{M}-\mathbf{N})$ & $\boldsymbol{v}\left(\mathbf{H}_{2} \mathbf{O}\right)$ \\
\hline $\mathrm{C}_{28} \mathrm{H}_{18} \mathrm{~N}_{6} \mathrm{Br}_{2}$ & 1668 & 3379 & 744 & - & - \\
\hline$\left[\mathrm{Ni}(\mathrm{L})\left(\mathrm{H}_{2} \mathrm{O}\right)_{2}\right]$ & 1587 & 3321 & 727 & 466 & 3603,819 \\
\hline$\left[\mathrm{Cu}(\mathrm{L})\left(\mathrm{H}_{2} \mathrm{O}\right)_{2}\right]$ & 1588 & 3304 & 738 & 467 & 3545,831
\end{tabular}

${ }^{1} H-N M R$ spectra.

The ${ }^{1} \mathrm{H}-\mathrm{NMR}$ spectra of the Schiff base ligand were recorded in DMSO. The chemical shifts $(\delta)$ are given in ppm downfield from tetramethylsilane. The spectrum also shows peaks between 7.16 to 7.08 ppm C-H proton of substituted benzene and $\mathrm{N}-\mathrm{H}$ proton of benzimidazole 
ring at $6.08 \mathrm{ppm}$. Two aromatic protons of the benzimidazole ring appear doublet in the proton range at $\delta=8.02$ to $7.16 \mathrm{ppm}[32]$.

\subsection{Mass spectra.}

The mass spectra of the ligand showed the molecular ion peak at $\mathrm{m} / \mathrm{z}=598$, which correspond to its molecular formula $\left[\mathrm{C}_{28} \mathrm{H}_{18} \mathrm{~N}_{6} \mathrm{Br}_{2}\right]$.

\subsection{Electronic spectra.}

The electronic spectra of $\pi-\pi^{*}$ and $n-\pi^{*}$ transition of metal complexes were recorded in DMSO solution in the region of 200 to $800 \mathrm{~nm}$ [33]. Ni(II) complex shows three bands at $36,364 \mathrm{~cm}^{-1}, 43,478 \mathrm{~cm}^{-1}, 48,309 \mathrm{~cm}^{-1}$ corresponding to the transitions ${ }^{3} \mathrm{~A}_{2 \mathrm{~g}} \rightarrow{ }^{3} \mathrm{~T}_{2 \mathrm{~g}}(\mathrm{~F})\left(\mathrm{v}_{1}\right),{ }^{3} \mathrm{~A}_{2 \mathrm{~g}}$ $\rightarrow{ }^{3} \mathrm{~T}_{1 \mathrm{~g}}(\mathrm{~F})\left(\mathrm{v}_{2}\right),{ }^{3} \mathrm{~A}_{2 \mathrm{~g}} \rightarrow{ }^{3} \mathrm{~T}_{2 \mathrm{~g}}(\mathrm{P})\left(\mathrm{v}_{3}\right)$, respectively [34]. This suggests octahedral stereochemistry around $\mathrm{Ni}(\mathrm{II})$ complex.

UV spectrum of $\mathrm{Cu}(\mathrm{II})$ complex showed three bands, $36,232 \mathrm{~cm}^{-1}, 36,765 \mathrm{~cm}^{-1}$ and $43,478 \mathrm{~cm}^{-1}$ corresponding to ${ }^{2} \mathrm{~B}_{1 \mathrm{~g}} \rightarrow{ }^{2} \mathrm{~A}_{1 \mathrm{~g}}\left(\mathrm{v}_{1}\right),{ }^{2} \mathrm{~B}_{1 \mathrm{~g}} \rightarrow{ }^{2} \mathrm{~B}_{2 \mathrm{~g}}\left(\mathrm{v}_{2}\right)$, and ${ }^{2} \mathrm{~B}_{1 \mathrm{~g}} \rightarrow{ }^{2} \mathrm{E}_{\mathrm{g}}\left(\mathrm{v}_{3}\right)$ transition in octahedral (Figure 1) geometry [35]. The electronic spectral data obtained for both the metal complexes are presented in table 4.

Table 4. Electronic spectral data of $\mathrm{Ni}$ (II) and $\mathrm{Cu}$ (II) complexes.

\begin{tabular}{c|c|c|c}
\multicolumn{1}{c}{ Complexes } & Frequency $\left(\mathrm{cm}^{-1}\right)$ & Assignment & Geometry \\
\hline \multirow{2}{*}[\mathrm{NiC}_{28}\mathrm{H}_{18}\mathrm{N}_{6}\mathrm{Br}_{2}(\mathrm{H}_{2}\mathrm{O})_{2}]{} & $36,364 \mathrm{~cm}^{-1}$ & ${ }^{3} \mathrm{~A}_{2 \mathrm{~g}} \rightarrow{ }^{3} \mathrm{~T}_{2 \mathrm{~g}}(\mathrm{~F})\left(\mathrm{v}_{1}\right)$ & \multirow{2}{*}{ Octahedral } \\
\cline { 2 - 3 } & $43,478 \mathrm{~cm}^{-1}$ & ${ }^{3} \mathrm{~A}_{2 \mathrm{~g}} \rightarrow{ }^{3} \mathrm{~T}_{1 \mathrm{~g}}(\mathrm{~F})\left(\mathrm{v}_{2}\right)$ & \\
\cline { 2 - 3 } & $48,309 \mathrm{~cm}^{-1}$ & ${ }^{3} \mathrm{~A}_{2 \mathrm{~g}} \rightarrow{ }^{3} \mathrm{~T}_{2 \mathrm{~g}}(\mathrm{P})\left(\mathrm{v}_{3}\right)$ & \\
\hline \multirow{2}{*}[\mathrm{Cu}\mathrm{C}\mathrm{C}_{28}\mathrm{H}_{18}\mathrm{N}_{6}\mathrm{Br}_{2}(\mathrm{H}_{2}\mathrm{O})_{2}]{} & $36,232 \mathrm{~cm}^{-1}$ & ${ }^{2} \mathrm{~B}_{1 \mathrm{~g}} \rightarrow{ }^{2} \mathrm{~A}_{1 \mathrm{~g}}\left(\mathrm{v}_{1}\right)$ & \\
\cline { 2 - 3 } & $36,765 \mathrm{~cm}^{-1}$ & ${ }^{2} \mathrm{~B}_{1 \mathrm{~g}} \rightarrow{ }^{2} \mathrm{~B}_{2 \mathrm{~g}}\left(\mathrm{v}_{2}\right)$ & \multirow{2}{*}{ Octahedral }
\end{tabular}

\subsection{DSC analysis of metal complexes.}

The DSC analyses of Ni (II) and Cu (II) metal complexes were conducted from room temperature to $360^{\circ} \mathrm{C}$. The DSC curves were obtained under a dynamic nitrogen atmosphere with a flow rate of $80 \mathrm{ml} \mathrm{min}-1$ and a heating rate of $10^{\circ} \mathrm{C} \mathrm{min}^{-1}$. The thermal data obtained from the thermogram of each metal complex is summarized in Table 5.

The Ni (II) complex undergoes decomposition in two stages as per the data obtained from the thermogram. The peak data may be explained as follows. The first stage occurred in the temperature range of $211.59^{\circ} \mathrm{C}$ to $239.39^{\circ} \mathrm{C}$ with a peak temperature of $227.15^{\circ} \mathrm{C}$. This corresponds to the dehydration process with the loss of coordinated water molecules. The second stage occurred in the temperature range of $259.63{ }^{\circ} \mathrm{C}$ to $276.44{ }^{\circ} \mathrm{C}$ with a peak temperature of $244.33{ }^{\circ} \mathrm{C}$. These endothermic peak values correspond to the decomposition of the ligand and the formation of Stable NiO. These two peak areas gave value of $\Delta \mathrm{H}=255.07$ Joules $/ g, \Delta H=-9.73 J$ oules $/ g$, respectively [36,37].

The $\mathrm{Cu}$ (II) complex undergoes decomposition in three stages as per the data obtained from the thermogram. The peak data may be explained as follows. The first stage occurred in the temperature range of $97.97{ }^{\circ} \mathrm{C}$ to $139.39{ }^{\circ} \mathrm{C}$ with a peak temperature of $118.02^{\circ} \mathrm{C}$. This corresponds to the dehydration process with the loss of coordinated water molecules. The second stage occurred in the temperature range of $171.88{ }^{\circ} \mathrm{C}$ to $223.37{ }^{\circ} \mathrm{C}$ with a peak temperature of $197.27{ }^{\circ} \mathrm{C}$. These endothermic peak values correspond to the partial 
decomposition of the ligand. The third stage occurred in the temperature range of $220.51{ }^{\circ} \mathrm{C}$ to $235.98{ }^{\circ} \mathrm{C}$ with a peak temperature of $231.22{ }^{\circ} \mathrm{C}$. These endothermic peak values show the partial decomposition of the ligand. The fourth stage occurred in the temperature range of $269.74{ }^{\circ} \mathrm{C}$ to $300.84{ }^{\circ} \mathrm{C}$ with a peak temperature of $286.37{ }^{\circ} \mathrm{C}$. These endothermic peak values show the decomposition of ligand and formation of Stable $\mathrm{CuO}$. These four peak areas gave value of $\Delta H=-56.11 \mathrm{Joules} / \mathrm{g}, \Delta \mathrm{H}=237.44 \mathrm{Joules} / \mathrm{g}, \Delta \mathrm{H}=23.24 \mathrm{Joules} / \mathrm{g}, \Delta \mathrm{H}=8.32 \mathrm{Joules} / \mathrm{g}$ respectively $[38,39]$.

Table 5. Differential Scanning Calorimetry (DSC) analyses of metal complexes.

\begin{tabular}{|c|c|c|c|c|c|c|}
\hline $\begin{array}{l}\text { Sr. } \\
\text { No }\end{array}$ & Complex & $\begin{array}{l}\text { Onset Temp. } \\
\text { in }{ }^{\circ} \mathrm{C}\end{array}$ & $\begin{array}{l}\text { Peak Temp. } \\
\text { in }{ }^{\circ} \mathrm{C}\end{array}$ & $\begin{array}{l}\text { End set Temp. } \\
\text { in }{ }^{\circ} \mathrm{C}\end{array}$ & $\begin{array}{l}\text { Transition Enthalpy } \\
(\Delta H) \text { Joules/g }\end{array}$ & $\begin{array}{c}\text { Sample Mass } \\
\text { in } \mathrm{mg}\end{array}$ \\
\hline \multirow{2}{*}{1} & \multirow{2}{*}{$\mathrm{Ni}-\mathrm{L}_{\mathrm{B}}$} & 211.59 & 227.15 & 239.39 & 255.07 & \multirow[t]{2}{*}{2.50} \\
\hline & & 259.63 & 244.33 & 276.44 & -9.73 & \\
\hline \multirow{4}{*}{2} & \multirow{4}{*}{$\mathrm{Cu}-\mathrm{LB}_{\mathrm{B}}$} & 97.97 & 118.02 & 139.39 & -56.11 & \multirow{4}{*}{2.56} \\
\hline & & 171.88 & 197.27 & 223.37 & 237.44 & \\
\hline & & 220.51 & 231.22 & 235.98 & 23.24 & \\
\hline & & 269.74 & 286.37 & 300.84 & 8.32 & \\
\hline
\end{tabular}

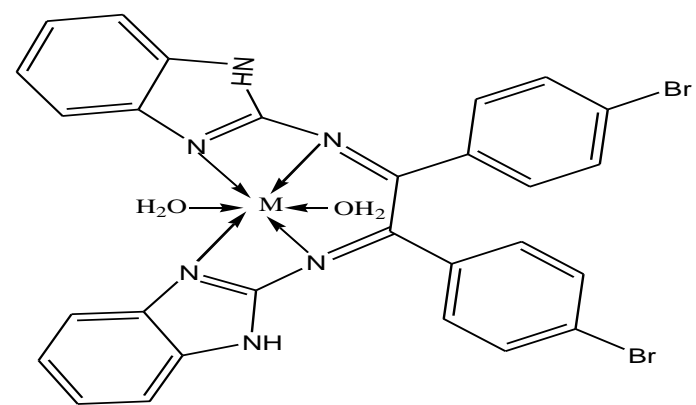

Figure 1. The proposed structure of the complexes when $\mathrm{M}=\mathrm{Mn}(\mathrm{II}), \mathrm{Fe}(\mathrm{III}), \mathrm{Co}(\mathrm{II}), \mathrm{Ni}(\mathrm{II}), \mathrm{Cu}(\mathrm{II}), \mathrm{Zn}$ (II), $\mathrm{Cd}$ (II) and $\operatorname{Ag}(\mathrm{I})$.

\subsection{Antibacterial activity.}

Antibacterial activity of Schiff base ligand and its complexes have been tested against bacteria, such as Escherichia coli, Staphylococcus aureus, and Salmonella typhi, which were grown overnight at $37^{\circ} \mathrm{C}$ temperature $[40,41]$. The standard strains were obtained from MTCC Chandigarh. Determination of minimum inhibitory concentrations (MIC) by Micro Broth Dilution Method was used to measure inhibition concentration wavelength at $475 \mathrm{~nm}$ was evaluated against test bacteria for the concentration ranging between $0.4 \mu \mathrm{g} / \mathrm{ml}$ to $100 \mu \mathrm{g} / \mathrm{ml}$ [42]. DMSO and compared with antibiotics viz. Streptomycin [43]. All the investigated compounds showed remarkable biological activity against bacteria in (Table.5). The obtained results reflect that; (1)The $\mathrm{Co}(\mathrm{II})$ and $\mathrm{Ni}(\mathrm{II})$ complexes exhibited very good antibacterial activity against Escherichia coli; (2) The Schiff base ligand, Ni(II), and Zn (II) complex showed good activity against Staphylococcus aureus bacteria ; (3)The ligand and $\mathrm{Co}$ (II), $\mathrm{Cu}$ (II) complex exhibited excellent antibacterial activity against Salmonella typhi. The parent ligand shows excellent antibacterial activity against Salmonella typhi.

\begin{tabular}{|c|c|c|c|c|}
\hline \multirow[t]{2}{*}{ Sr. No. } & \multirow[t]{2}{*}{ Compounds } & \multicolumn{3}{|c|}{ Minimal inhibition Concentration $(\mu \mathrm{g} / \mathrm{ml})$} \\
\hline & & E. coli & S. aureus & S. typhi \\
\hline 1 & Ligand & 250 & 100 & 50 \\
\hline 2 & Mn(II) & 250 & 125 & 500 \\
\hline
\end{tabular}




\begin{tabular}{c|c|c|c|c}
\multirow{2}{*}{ Sr. No. } & \multirow{2}{*}{ Compounds } & \multicolumn{3}{|c}{ Minimal inhibition Concentration $(\boldsymbol{\mu g} / \mathbf{m l})$} \\
\cline { 3 - 5 } & & $\boldsymbol{E}$. coli & S. aureus & S. typhi \\
\hline 3 & $\mathrm{Fe}(\mathrm{III})$ & 250 & 125 & 250 \\
\hline 4 & $\mathrm{Co}(\mathrm{II})$ & 100 & 125 & 100 \\
\hline 5 & $\mathrm{Ni}(\mathrm{II})$ & 100 & 100 & 250 \\
\hline 6 & $\mathrm{Cu}(\mathrm{II})$ & 250 & 125 & 125 \\
\hline 7 & $\mathrm{Zn}(\mathrm{II})$ & 500 & 100 & 500 \\
\hline 8 & $\mathrm{Cd}(\mathrm{II})$ & 500 & 500 & 250 \\
\hline 9 & $\mathrm{Ag}(\mathrm{I})$ & 500 & 125 & 500
\end{tabular}

\section{Conclusions}

In the present work, we successfully designed and developed N-((E)-2(1Hbenzo[d]imidazol-2-ylimino)-1,2-bis (4-bromophenyl) ethylidene)-1Hbenzo[d]imidazol2-amine and its metal complexes. The ligand and its complexes have been characterized by various spectral analyses. Obtained results were in good agreement with the proposed structure. The microwave method has been considered a green chemical route. As the result of microwave-assisted synthesis, it has been observed that reaction time decreased from hours to minutes, and availability of product better yield. This method is simple, mild, and eco-friendly from a green chemistry point of view. Based on the electronic spectra, thermal study data octahedral geometry has been suggested for $\mathrm{Ni}$ (II), $\mathrm{Cu}$ (II) complexes.

\section{Funding}

The entire research work is self-funded.

\section{Acknowledgments}

The authors are thankful to the Head, Department of chemistry, and Principal, J.E.S. College, Jalna India, for providing the laboratory facilities. MSS'S Arts Science and Commerce College, Ambad, India, for their support.

\section{Conflicts of Interest}

There is no conflict of interest of any kind of the authors involved in this work.

\section{References}

1. Aghayan, M.; Ghassemzadeh, M.; Hoseini, M.; Bolourtchian, M. Microwave-Assisted synthesis of the tetradendate Schiff bases under solvent free and catalyst free condition. Synth.Comm. 2003, 33, 521-525, https://doi.org/10.1081/SCC-120015804.

2. Bhale, S.; Gore, V.; Tekale, S.; Pawar, R. P. Synthesis, Characterization and Antimicrobial Activity of Ni(II), $\mathrm{Zn}(\mathrm{II})$, and $\mathrm{Cd}(\mathrm{II})$ Complexes of 3/4-Bromo-Benzoic Acid (Phenyl-Pyridine-2-yl-Methylene)-Hydrazide Ligand,Letters in Applied NanoBioscience $\quad$ 2020, $\quad 4, \quad$ 1529-1537, https://doi.org/10.33263/LIANBS94.15291537.

3. Das, S.; Das, V.K.; Saikia, L.; Thakur AJ. Environmentally friendly and solvent free synthesis of symmetric bis-imines under microwave irradiation.Green Chem. Lett. Rev. 2012, 5, 457-474, https://doi.org/10.1080/17518253.2012.667443.

4. Asiri, A.M. and Khan, S.A. Synthesis and antibacterial activities of some novel Schiff bases derived from aminophenazone. Molecules 2010, 15, 6850-6858, https://doi.org/10.3390/molecules15106850.

5. Noorussabah, N.; Choudhary, M.; Das, N.; Mohan, B.; Singh, K.; Singh, R.K.; Ahmad, K.; Muhammad, S.; Kumar, S. Copper(II) and Nickel(II) Complexes of Tridentate Hydrazide and Schiff Base Ligands Containing Phenyl and Naphthalyl Groups: Synthesis, Structural, Molecular Docking and Density Functional Study. 
Journal of Inorganic and Organometallic Polymers and Materials 2020, 30, 4426-4440, https://doi.org/10.1007/s10904-020-01610-w.

6. Mahajan, K. Swami, M. and Singh, R. V."Microwave Synthesis, Spectral Studies, Antimicrobial Approach and Coordination Behavior of Antimony (III) and Bismuth (III) Compounds with Benzothiazoline. Russian Journal of Coordination Chemistry 2009, 35, 179- 185, https://doi.org/10.1134/S1070328409030038.

7. Manimohan, M.; Pugalmani, S.; Sithique, M.A. Biologically active novel N, N, O donor tridentate water soluble hydrazide based O-carboxymethyl chitosan Schiff base $\mathrm{Cu}$ (II) metal complexes: Synthesis and characterization. International Journal of Biological Macromolecules 2019, 136, 738-754, https://doi.org/10.1016/j.ijbiomac.2019.06.115.

8. Sharma K, Singh RV,Fahmi N and Singh RV"Microwave Assisted Synthesis, Characterization and Biological Evaluation of Palladium and Platinum Complexes with Azomethines. Spectro- chimica Acta 2010 75A, 422-427, https://doi.org/10.1016/j.saa.2009.10.052.

9. Kumar, S.S.; Biju, S.; Sadasivan, V. Synthesis, structure characterization and biological studies on a new aromatic hydrazone, 5-(2-(1, 5-dimethyl-3-oxo-2-phenyl-2, 3-dihydro-1H-pyrazol-4-yl) hydrazono)-2, 2dimethyl-1, 3-dioxane-4, 6-dione, and its transition metal complexes. Journal of Molecular Structure 2018, 1156, 201-209, https://doi.org/10.1016/j.molstruc.2017.11.057.

10. Salahuddin; Shaharyar, M; Mazumder, A.; Abdullah M.M. Synthesis, characterization and antimicrobial activity of 1,3,4-oxadiazole bearing 1H-benzimidazole derivatives.Arabian Journal of Chemistry 2017, 10, 503-S508, https://doi.org/10.1016/j.arabjc.2012.10.010.

11. Suresh, S.; Karthikeyan, S.; Saravanan, P.; Jayamoorthy, K.; Dhanalekshmi, K.I. Comparison of antibacterial and antifungal activity of 5-amino-2- mercapto benzimidazole and functionalized $\mathrm{Ag}_{3} \mathrm{O}_{4}$ nanoparticles. Karbala International Journal of Modern Science $\quad$ 2016, 2 129-137, https://doi.org/10.1016/j.kijoms.2016.03.003.

12. El-Gammal, O.A.; Abu El-Reash, G.M.; Goama, H.E. Mononuclear Cr(III), Mn (II), and Fe(III) complexes derived from new ONO symmetrical flexible hydrazone: synthesis, spectral characterization, optical band gap and DFT computational study. Letters in Applied NanoBioScience 2019, 8, 743-753, https://doi.org/10.33263/LIANBS84.743753.

13. Ramya Rajan,M.P.; Rathikha, R.; Nithyabalaji, R.; Sribalan, R. Synthesis, characterization, in silico studies and in vitro biological evaluation of isoniazid-hydrazone complexes. J. Mol. Struct 2020, 1216, 128297, https://doi.org/10.1016/j.molstruc.2020.128297.

14. Vinoth, G.; Indira, S.; Bharathi, M.; Alves, L.G.; Martins, A.M.; Shanmuga Bharathi, K. Cyanosilylation of carbonyl compounds catalyzed by half-sandwich ( $\eta 6-p-c y m e n e)$ Ruthenium (II) complexes bearing heterocyclic hydrazone derivatives. Inorg. Chim. Acta 2021, 514, 120006, https://doi.org/10.1016/j.ica.2020.120006.

15. Refaat, H.M.; Synthesis and anticancer activity of some novel 2-substituted benzimidazole derivatives. European Journal of Medicinal Chemistry 2010, 45, 2949-2956, https://doi.org/10.1016/j.ejmech.2010.03.022.

16. Padalkar, V.S.; Borse, B.N.; Gupta, V.D.; Phatangare, K.R.; Patil, V.S.; Umape, P.G.; Sekar, U.N. Synthesis and antimicrobial activity of novel 2-substituted benzimidazole, benzoxazole and benzothiazole derivatives Arabian Journal of Chemistry 2016, 9,1125-S1130, https://doi.org/10.1016/j.arabjc.2011.12.006.

17. Khan, M.I.; Xu, S.; Ali, M.M.; Ali, R.; Kazmi, A.; Akhtar, N.; Bilal, M.; Hu, Y.; Li, F. Assessment of multidrug resistance in bacterial isolates from urinary tract-infected patients. J. Rad. Res. \& Appl. Sci. 2020, 13, 267-275, https://doi.org/10.1080/16878507.2020.1730579.

18. Concha, C.; Quintana, C.; Klahn, A.H.; Artigas, V.; Fuentealba, M.; Biot, C.; Halloum, I.; Kremer, L.; López, R.; Romanos, J.; Huentupil, Y. Organometallic tosyl hydrazones: Synthesis, characterization,crystal structures and in vitro evaluation for anti-mycobacterium tuberculosis and antiproliferative activities. Polyhedron 2017, 131, 40-45, https://doi.org/10.1016/j.poly.2017.04.031.

19. Shaharyar M, Mazumder A, Salahuddin, Garg R, Pandey RD. Synthesis, characterization and pharmacological screening of novel benzimidazole derivatives. Arabian Journal of Chemistry 2016, 9, 342S347, https://doi.org/10.1016/j.arabjc.2011.04.013.

20. Shaker, Y.M.; Omar, M.A.; Mahmoud, K.; Elhallouty, S.M.; El-Senousy, W.M.; Ali, M.M.; Mahmoud, A.E.; Abdel-Halim, A.H.; Soliman, S.M.; El Diwani, H.I. Synthesis, in vitro and in vivo antitumor and antiviral activity of novel 1-substituted benzimidazole derivatives. Journal of Enzyme Inhibition and Medicinal Chemistry 2015 , 30, 826-845, https://doi.org/10.3109/14756366.2014.979344. 
21. Pocrnić, M.; Kontrec, D.; Miljanić, S.; Soldin, Ž.; Budimir, A.; Galić, N. Gallium(III) complexes of aroylhydrazones derived from nicotinic acid hydrazide in solid state and in solution. J. Mol. Struct. 2021, 1227, 129564, https://doi.org/10.1016/j.molstruc.2020.129564.

22. Tonelli, M.; Paglietti, G.; Boido, V.; Sparatore, F.; Marongiu, F.; Marongiu, E.; La Colla, P.; Loddo R. Antiviral activity of benzimidazole derivatives. I. Antiviral activity of 1-substituted-2-[(benzotriazol-1/2yl)methyl]benzimidazoles. Chem Biodivers 2008, 5, 2386-401, https://doi.org/10.1002/cbdv.200890203.

23. Jat, R.K.; Jat, J.L.; Pathak, D.P.; Synthesis of Benzimidazole Derivatives: As Anti-Hypertensive Agents. Journal of Chemistry 2006, 3, 278-285, https://doi.org/10.1155/2006/765712.

24. Bhale, S.; Tekale, S.U.; Kohire, R.; Phase, R.; Pawar, R. Synthesis, characterization, antimicrobial activity and transition metal complexes of 3-bromo-N'-(1-(5-chloro-2-hydroxyphenyl) ethylidene) benzohydrazide ligand. Current Pharma Research 2019, 9, 3283-3289.

25. Evans, T.M.; Gardiner, J.M.; Mahmood ,N.; Smis, M. Structure-activity relationships of anti-HIV-1 Nalkoxy- and $N$-allyloxy-benzimidazoles. Bioorganic \& Medicinal Chemistry Letters 1997, 7, 409-412, https://doi.org/10.1016/S0960-894X(97)00022-X.

26. Fun, H.K.; Kia, R.; Vijesh, A.M.; Isloor, A.M. 5-Diethylamino-2-[(E)-(4-methyl-3-nitrophenyl) iminomethyl] phenol: are determinations. Acta Crystallographica E: Structure Reports Online 2009, 65, 0349-035, https://doi.org/10.1107/S1600536809001731.

27. Venugopal, P.; Krishnakuty, K. Synthesis and characterization of cobalt-nickel,copper- and zinc(II) complexes of morin. J. Indian Chem. Soc. 1997, 74, 562-563.

28. Dharmaraj, N.; Viswanathamurthi, P.; Nataragan, K. Ruthenium(II) complexes containing bidentate Schiff bases and their antifungal activity. J. Transition Met. Chem. 2001, 26, 105-109.

29. Omidi, S.; Kakanejadifard, A. A review on biological activities of Schiff base, hydrazone, and oxime derivatives of curcumin. RSC Advances 2020, 10, 30186-30202, https://doi.org/10.1039/D0RA05720G.

30. Mishra, A.P.; Rajendra, K. Jain. Conventional and microwave synthesis, spectral, thermal and antimicrobial studies of some transition metal complexes containing 2-amino-5-methylthiazole moiety. Journal of Saudi Chemical Society 2014, 18, 814-824, https://doi.org/10.1016/j.jscs.2011.09.013.

31. Okagu, O.D.; Ugwu, K.C.; Ibeji, C.U.; Ekennia, A.C.; Okpareke, O.C.; Ezeorah, C.J.; Anarado, C.J.O.; Babahan, I.; Coban, B.; Yıldız, U.; Cömert, F.; Ujam, O.T. Synthesis and characterization of Cu(II), Co(II) and $\mathrm{Ni}(\mathrm{II})$ complexes of a benzohydrazone derivative: Spectroscopic, DFT, antipathogenic and DNA binding studies. J. Mol. Struct. 2019, 1183, 107-117, https://doi.org/10.1016/j.molstruc.2019.01.069.

32. Pandey, M.K.; Sandur, S.K.; Sung, B.; Sethi, G.; Kunnumakkara, A.B.; Aggarwal, B.B. Butein, a tetrahydroxychalcone, inhibits nuclear factor (NF)-B and NF-B regulated gene expression through direction inhibition of IB kinase on cysteine 179 residue. J. Biol. Chem. 2007, 282, 17340-17350, https://doi.org/10.1074/jbc.M700890200.

33. Sharma, S.T.; Mehta, M.K.; Shah. Synthesis and spectral studies of transition metal complexes supported by NO-bidentate Schiff base ligand. Der. Chem. Sin. 2013, 4, 141-146, https://www.imedpub.com/abstract/synthesis and spectral studies of transition metal complexes supported byrnnobidentate schiffbase ligand-12465.html.

34. Dikmen, G.; Ünver, H. A new Pd(II) Hydrazide Triphenylphosphine complex: Synthesis, crystal structure, spectroscopic characterization and theoretical calculations. J. Mol. Struct. 2021, 1225, 129139, https://doi.org/10.1016/j.molstruc.2020.129139.

35. Shirodkar, S.G.; Mane, P.S.; Chondhekar, T.K.; Synthesis and fungitoxic studies of Mn(II), Co(II), Ni(II), $\mathrm{Cu}(\mathrm{II})$ with some heterocyclic Schiff base ligands. Indian J. Chem. 2001, 40A, 1114-1117, https://www.researchgate.net/publication/332291763Synthesis and fungitoxic studies of MnII CoII NiII and CuII with some heterocyclic Schiff base ligands.

36. Reddy, P,S.; Ananthalakshmi, P.V.; Jayatyaga, V.R. Synthesis and structural studies of first row transition metal complexes with tetradentate ONNO donor Schiff base derived from 5-acetyl 2,4dihydroxyacetophenone and ethylenediamine. E-J. Chem. 2011, 8, 415-420, https://doi.org/10.1155/2011/536269.

37. A.B.P.Lever."Inorganic Electronic Spectroscopy", Elsevier Publishing Company, Amsterdam 1968, 333-341, 356-360, https://doi.org/10.1021/ed046pA628.1.

38. S.U. Din; M. Umar. Thermal Stability of Bis-Piperidine Benzoylacetonates of Some Transition Metals. $J$. Therm. Anal. Calorim. 1999, 58, 61, https://doi.org/10.1023/a:1010191503434. 
39. M.Lalia-Kantouri, L.; Tzavellas, D.; Paschalidis. Novel lanthanide complexeswith di-2-pyridyl ketone- $p$ chloro-benzoylhydrazone Thermal investigation by simultaneous TG/DTG-DTA and IR spectroscopy. $J$ Therm.Anal. Calorim.2008, 91, 937, https://doi.org/10.1007/s10973-007-8487-8.

40. Banfi, E.; Scialino, G.; Monti-Bragadin, C. Development of a microdilution method to evaluate Mycobacterium tuberculosis drug susceptibility. Journal of Antimicrobial Chemotherapy 2003, 52, 796-800, https://doi.org/10.1093/jac/dkg439.

41. Stalons, D.R.; Thornsberry, C. Broth-dilution method for determining the antibiotic susceptibility of anaerobic bacteria. Antimicrob. Agents Chemother. 1975, 7, 15-21, https://doi.org/10.1128/AAC.7.1.15.

42. Balouiri, M.; Sadiki, M.; Ibnsouda, S.K.; Methods for in vitro evaluating antimicrobial activity: A review. $J$ Pharm Anal. 2016, 6, 71-79, https://doi.org/10.1016/j.jpha.2015.11.005.

43. Furniss, B.S.; Hannaford, A.J.; Smith, P.W.J.; Tatechell, A.R.; Vogel's Textbook of Practical Organic Chemistry. Longman, New York. 1989, 5, 1193, https://vdoc.pub/documents/vogels-textbook-of-practicalorganic-chemistry-6sci8fluahu0. 